\title{
Pseudohyponatraemia due to L-asparaginase- associated dyslipidaemia in T-cell lymphoblastic lymphoma
}

\author{
Jaimal Kothari, Alison Thomas, Anthony Goldstone
}

University College Hospital, London, UK

\section{Correspondence to} Dr Jaimal Kothari, jaimal.kothari@nhs.net

Accepted 18 February 2014

\section{CrossMark}

To cite: Kothari J, Thomas A, Goldstone A. BMJ Case Rep Published online: [please include Day Month Year] doi:10.1136/ bcr-2013-202829

\section{DESCRIPTION}

A 22-year-old man presented with a 3-month history of fatigue and dry cough. Chest X-ray demonstrated an anterior mediastinal mass, and biopsy showed T-cell lymphoblastic lymphoma (T-ALL). Investigations showed a widespread nodal disease, but with no detectable bone marrow or central nervous system involvement.

On day 26 , he was noted to have mild hyponatraemia (sodium $126 \mathrm{mmol} / \mathrm{L}$ NR 135-145). On day 27 , the clinicians were contacted by the laboratory technicians who were unable to accurately measure any electrolytes due to the lipaemia interfering with the indirect ion-specific electrode (ISE) methodology of the analyser.

A sample of the patient's blood (in trisodium citrate) is shown in figure 1 . Triglyceride levels were $66.5 \mathrm{mmol} / \mathrm{L}$ (NR 0.4-2.3), with marked concurrent hyperglycaemia. Management with an insulin sliding scale and dietary restriction resulted in normalisation of triglycerides after 5 days. $\mathrm{He}$ has subsequently entered remission for his T-ALL and remains well. Further doses of asparaginase were omitted.

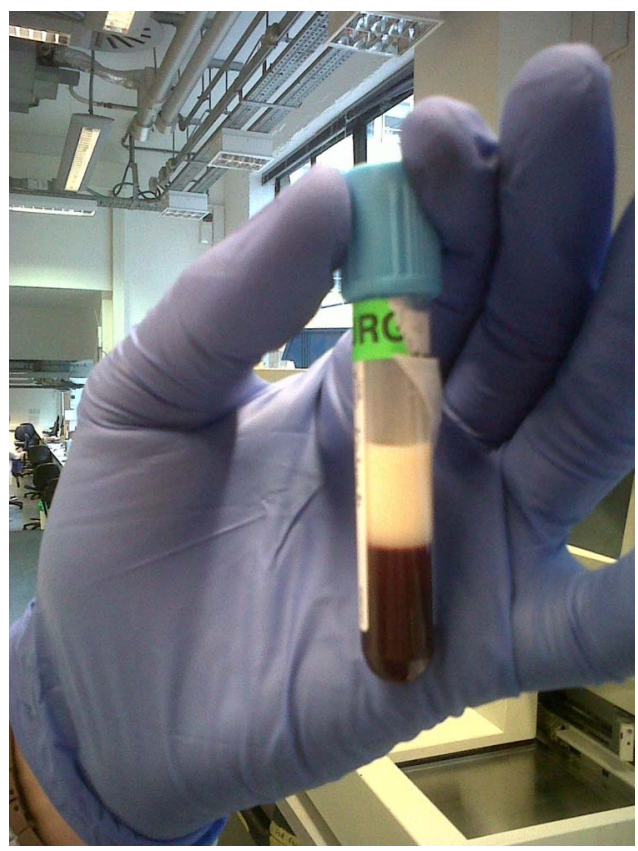

Figure 1 Patient's blood in a trisodium citrate vacutainer, highlighting the separation of a marked fatty layer, indicative of extreme lipaemia.
Hypertriglyceridaemia is a well-recognised cause of pseudohyponatraemia, which was the first indication of lipid perturbation in this patient. Many routine automated biochemical analysers measure electrolyte activity using indirect ISE, and concentrations are then calculated using a conversion equation based on the properties of standard plasma. Hyperlipidaemia interferes with the conversion methodology, thus rendering the electrolytes unanalysable.

Asparaginase has been proved to be a highly efficacious addition to induction regimes for T-ALL but has a marked side effect profile including allergic reactions, thrombosis, pancreatitis, hepatic toxicity and hypertriglyceridaemia.

\section{Learning points}

- Hypertriglyceridaemia is a well-recognised complication of L-asparaginase therapy and can cause pseudohyponatraemia.

- Biochemical analysers using direct ion-specific electrode methodology may be used in such situations, although the results of the direct and indirect methods are not strictly equivalent.

- Management of hyperlipidaemia with drug discontinuation, insulin administration with careful monitoring and, in extreme cases, with plasmapheresis ${ }^{1}$ or fenofibrate, ${ }^{2}$ avoids serious complications such as pancreatitis.

Contributors JK and AT wrote the manuscript. AT provided the clinical photo, and AG critically reviewed and edited the manuscript. All authors approved the final version.

Competing interests None.

Patient consent Obtained.

Provenance and peer review Not commissioned; externally peer reviewed.

\section{REFERENCES}

1 Kfoury-Baz EM, Nassar RA, Tanios RF, et al. Plasmapheresis in asparaginase-induced hypertriglyceridemia. Transfusion 2008;48:1227-30.

2 Seah J, Lin K, Tai D, et al. Conservative management of L-asparaginase-induced hypertriglyceridemia in an adult patient: a case report and review of the literature. Onkologie 2012;35:596-8. 
Copyright 2014 BMJ Publishing Group. All rights reserved. For permission to reuse any of this content visit http://group.bmj.com/group/rights-licensing/permissions.

BMJ Case Report Fellows may re-use this article for personal use and teaching without any further permission.

Become a Fellow of BMJ Case Reports today and you can:

- Submit as many cases as you like

- Enjoy fast sympathetic peer review and rapid publication of accepted articles

- Access all the published articles

- Re-use any of the published material for personal use and teaching without further permission

For information on Institutional Fellowships contact consortiasales@bmjgroup.com

Visit casereports.bmj.com for more articles like this and to become a Fellow 